\title{
Efficacy of vaccine-induced Vif-specific CTL responses against SIVmac239 infection: implications for antigen design in AIDS vaccines
}

\author{
N Iwamoto ${ }^{\text {* }}$, N Takahashi ${ }^{1}$, T Nomura $^{1}$, H Yamamoto ${ }^{2}$, T Matano ${ }^{1}$ \\ From AIDS Vaccine 2012 \\ Boston, MA, USA. 9-12 September 2012
}

\section{Background}

Optimization of antigens as well as delivery system is crucial for development of an effective T-cell based AIDS vaccine. Our recent results suggested higher antiviral efficacy of Vif- and Nef-specific CTLs as well as Gag-specific ones (JEM 199:1709, 2004; AIDS 24:2777, 2010). Here, we examined efficacy of Gag-specific or Vif/Nef-specific CTL induction by vaccination against SIV infection.

\section{Methods}

All 17 animals used in this study were Burmese rhesus macaques sharing MHC-I haplotype 90-010-Ie, which mostly show typical AIDS progression after SIVmac239 challenge (geometric means of setpoint plasma viral loads: $10^{\wedge} 5$ copies $/ \mathrm{ml}$; mean survival periods: 2 years). These animals were divided into three groups consisting of unvaccinated $(\mathrm{n}=6)$, Gag-vaccinated $(\mathrm{n}=5)$, and Vif/Nef-vaccinated $(n=6)$; the latter two were subjected to DNA-prime/Sendai virus vector-boost vaccination. We compared these three groups after an intravenous SIVmac239 challenge.

\section{Results}

After challenge, 3 out of 5 Gag-vaccinated and 3 out of $6 \mathrm{Vif} / \mathrm{Nef}$-vaccinated animals controlled SIV replication. The SIV control was associated with Gag-specific CTL responses in the former and Vif-specific CTL responses in the latter.

${ }^{1}$ National Institute of Infectious Diseases, \& IMS, University of Tokyo, Tokyo, Japan

Full list of author information is available at the end of the article

\section{Conclusion}

This is the first report indicating efficacy of vaccineinduced Vif-specific CTL responses against SIV replication. Our results imply that not only Gag but also Vif may be a promising antigen for $\mathrm{T}$-cell based AIDS vaccines.

\section{Author details}

'National Institute of Infectious Diseases, \& IMS, University of Tokyo, Tokyo, Japan. ${ }^{2}$ National Institute of Infectious Diseases, Tokyo, Japan.

Published: 13 September 2012

doi:10.1186/1742-4690-9-S2-P26

Cite this article as: Iwamoto et al: Efficacy of vaccine-induced Vifspecific CTL responses against SIVmac239 infection: implications for antigen design in AIDS vaccines. Retrovirology 2012 9(Suppl 2):P26.

Submit your next manuscript to BioMed Central and take full advantage of:

- Convenient online submission

- Thorough peer review

- No space constraints or color figure charges

- Immediate publication on acceptance

- Inclusion in PubMed, CAS, Scopus and Google Scholar

- Research which is freely available for redistribution

Submit your manuscript at www.biomedcentral.com/submit
Ciomed Central

\section{Biomed Central}

